\title{
24. THE GOBAN SPUR PALEOZOIC BASEMENT ${ }^{1}$
}

\author{
Jean Pierre Lefort and Jean Jacques Peucat, Centre Armoricain d'Étude Structurale des Socles, Institut de \\ Géologie de l'Université de Rennes \\ and \\ Jean Deunff and Alain Le Herissé, Département des Sciences de la Terre, Université de Bretagne Occidentale ${ }^{2}$
}

\begin{abstract}
Paleozoic basement samples were recovered from two sites on the Goban Spur. The rock from one site is dated as middle Devonian; that from the other is unfossiliferous and could be Devonian or lower Carboniferous in age. The existence of a weak penetrative cleavage in the samples provides a link between the highly deformed upper Paleozoic strata of western Europe and the less deformed Carboniferous rocks known from north of Newfoundland.

The low metamorphic grade of the specimens suggests that the main Hercynian metamorphic belt lies south of the sample sites.
\end{abstract}

\section{INTRODUCTION}

Samples of Paleozoic basement were acquired near the Goban Spur, which is part of the continental margin of northwest Europe, to investigate the metamorphic and deformational history of the region. Such a history would allow this part of the European continental shelf to be designated as lying either in the main Hercynian belt of relatively intense tectonothermal effects or in the Hercynian foreland. The continental shelf is important in the development of correlations between western $\mathrm{Eu}-$ rope and the Grand Banks of Newfoundland, where Hercynian deformation is now recognized (Lefort and Haworth, in press). The study was also undertaken to determine the nature of the seismic reflectors within the Paleozoic basement that have been recorded south of the Porcupine Bank (Bailey, 1975); the Bank was close to the Goban Spur before the Porcupine Sea Bight opened during the Mesozoic (Lefort and Max, in press).

\section{SAMPLES AND RESULTS}

\section{Hole 548}

The basement samples from Site 548 (Cores 36-38) were recovered between 530 and $551 \mathrm{~m}$ below seafloor (BSF). There are a few large chips and blocks (the biggest being $10 \mathrm{~cm}$ in length) of unfossiliferous gray quartzites and shiny black shales. The quartzites are fine grained and display a poorly defined, finely laminated bedding; in thin section some of the samples are arkosic sandstones with deeply altered feldspar, detrital muscovite, chlorite, and some zircon. Black argillaceous layers between the quarzitic bands locally show an oriented mica sheen that reflects the orientation of fine-grained

\footnotetext{
${ }^{1}$ Graciansky, P. C. de, Poag, C. W., et al., Init. Repts. DSDP, 80: Washington (U.S. Govt, Printing Office).

2 Address: (Lefort, Peucat) Centre Armoricain d'Étude Structurale des Socles, Institut de Géologie de l'Université de Rennes, Campus de Beaulieu, 35042 Rennes Cedex, France; (Deunff, Le Herissé) Département des Sciences de la Terre, Université de Bretagne Occidentale, Avenue Le Gorgeu, 29283 Brest Cedex, France.
}

phyllosilicates, although this weak cleavage is not visible in the coarser grained portions of the samples.

The palynological study concentrated on Core 38, but Cores 36 and 37 do not show markedly different associations. There are two types of organic residue, broken fragments of acritarchs, which dissolve in the oxidizing process, and big pieces of plant tissues and spores.

The acritarchs were identified as Ammonidium, Micrhystridium, M. cf. adductum (Wicander, 1974), Multiplicisphaeridium, ?Staplinium, Polyedryxium cf. diabolicum (Deunff, 1971), P. simplex, and ?Palacanthus.

Spores are relatively common in the samples, but they are poorly preserved. The assemblage contains abundant acamerates and some small-sculptured forms, in addition to prominently spined zonate camerate spores of large size, such as Grandispora. The following species of spores were identified: Retusotriletes rotundus (Streel) (Lele and Streel, 1969): Retusotriletes sp.; Punctatisporites spp.; Aneurospora sp.; Emphanisporites annulatus (McGregor, 1973); Acinosporites acanthomamillatus (Richardson, 1965); Cymbosporites sp.; Verrucosisporites? polygonalis (Lanninger, 1968); Verruciretusispora sp.; Perotriletes cf. ergatus (Allen, 1965); Rhabdosporites sp.; and Grandispora spp.

A middle Devonian age is suggested for the shale and quartzite sequence and a subcontinental to marine environment for the depositional facies.

\section{Hole 549}

The basement samples at Site 549 (Cores 94-99) were taken from between 964.5 and $1001.5 \mathrm{~m}$ BSF. They are fine to medium grained, laminated and cross-laminated sandstones that are at times roseate, light olive brown, dark yellowish brown, or dark gray. They appear superficially to belong to the "Old Red Sandstone" facies. Bedding is well defined locally, and coarse-grained beds are sometimes iron stained dark brown. The core samples have fracture cleavage planes that are oriented parallel to the coring direction (vertical); some of these are striated or filled with fine-grained aggregates of phyllo- 
silicate. The vertical planes may be related to upper $\mathrm{Pa}-$ leozoic upright compression or to Mesozoic extensional tectonics.

On a microscopic scale there seems to be no penetrative deformation. There is a weak mineral fabric, however, in which quartz (c-axes) are parallel to the sedimentary layers, suggesting hydrodynamic deposition. In addition, small through cross-beds and tangential planar cross-beds were observed in the core samples. The micas are probably all detrital in origin. There is no clear recrystallization or rimming of quartz or mica; the sandstones display only minor diagenetic effects and no metamorphism. This low metamorphic grade does not prove that there is no deformation in the area, however. In Ireland, for instance, similar upper Paleozoic rocks are associated with severe regional folding, and the metamorphism is of equally low grade. Although no clear macroscopic deformation is visible in the samples, the nearly vertical bedding reported in the shipboard files suggests that either large-scale folding or tilting is associated with major faulting in the sandstones. The Goban Spur sandstones resemble some Irish Devonian and lower Carboniferous sandstones in composition, diagenesis, and general aspect.

No species of microflora (chitinozoans or acritarchs) have been recovered, even in the argillaceous layers in this sample set of cores.

A geochronological study was carried out using the $\mathrm{Rb}-\mathrm{Sr}$ measurements by mass spectrometry on the muscovites. For one bulk mineral sample, Rb content was $243 \mathrm{ppm}$ and $\mathrm{Sr}$ content was $30.7 \mathrm{ppm} .{ }^{87} \mathrm{Rb} /{ }^{86} \mathrm{Sr}$ and ${ }^{87} \mathrm{Sr} /{ }^{86} \mathrm{Sr}$ were respectively 23.5 and $0.95751 \pm 6\left(\lambda^{87} \mathrm{Rb}\right.$ $=1.42 \times 10^{-11} / \mathrm{yr}$.).

By using different reasonable ${ }^{87} \mathrm{Sr} /{ }^{86} \mathrm{Sr}$ initial ratios, theoretical ages can be calculated for these data. For a ratio of 0.710 , the age is $742 \mathrm{~m}$.y.; for 0.720 , the age is $712 \mathrm{~m} . \mathrm{y}$; and for 0.730 , the age is $682 \mathrm{~m} . \mathrm{y}$.

These ages (of about 700 m.y.) probably reflect the age of formation of the micas during the Cadomian tectonothermal event. Cadomian basement is known on the Grand Banks of Newfoundland (Haworth and Lefort, 1979), south of Ireland (Max, 1975), and in Brittany (Vidal, 1976). In any case, the values show that neither the Caledonian nor the Hercynian metamorphism was intense enough to re-equilibrate the muscovites isotopically, which suggests that the area probably was not subjected to a temperature higher than about $450^{\circ} \mathrm{C}$ after the deposition of the sandstones. Although it is not likely, there is also a possibility that the muscovites are older than Cadomian and have a diagenetic overprint.

The weak metamorphism at Hole 549 is in good agreement with the preservation of microfossil, pollen, and plant remains seen in Hole 548, and it suggests that no important Paleozoic metamorphism affected these Goban Spur rocks, which are Devonian and perhaps lower Carboniferous in age.

\section{CONCLUSIONS}

The weak cleavage in the rock specimens of the Goban Spur does not provide any real constraint for the position of the Hercynian front, since intense cleavage and folding of Hercynian age is known south as well as north of this position in England and Ireland (Matthews, 1974; Max, 1979; Max and Lefort, in press). Furthermore, the Hercynian deformation may extend beyond the western end of the European continental crust; folding has been recorded in Carboniferous strata north of Newfoundland (Lefort and Haworth, in press), and weak cleavage has been observed in some samples from wells on the Grand Banks of Newfoundland and the Labrador continental shelf. Because the metamorphism on the Grand Banks of Newfoundland and in our samples is weak, Sites 548 and 549 are probably north of the main Hercynian metamorphic belt of Europe, although the levels of deformation and metamorphism tend to be variable as one proceeds away from the center of the Hercynian orogenic belt, whose tectonometamorphic effects do not always diminish progressively northwestward.

The samples collected by the DSDP drilling on the Goban Spur improve our knowledge of the geology between the Fastnet Basin (Robinson et al., 1981) and the Menez Braz area (Pautot et al., 1976; Auffret et al., 1979; Dingle and Scrutton, 1979). Three zones can now be distinguished (Fig. 1). A northern underwater ridge trends northeast, following an axis of roughly $50^{\circ} \mathrm{E}$, as do all the basement highs of the South Irish Sea (Dingle and Scrutton, 1979). The ridge is constituted of Devonian sandstones and is bounded on the south by a Devonian to Carboniferous basin filled with shales and slates. Both the ridge and the basin are interrupted in the west by a plutono-metamorphic zone that probably represents a deeper basement level that was uplifted and eroded during the Mesozoic doming.

Although the samples collected in the area are not absolutely contemporaneous in age, the difference in the sedimentary facies between the ridge and the basin could be used as the approximate southern limit of the nonmarine Old Red Landmass (Devonian supercontinent) known in Ireland and Newfoundland and the shallow marine facies of Devonian age seen in the southeast in Cornwell and Brittany (Friend, 1969).

\section{ACKNOWLEDGMENTS}

Many thanks are due to M. D. Max and the six anonymous sedimentologists of the Geological Survey of Ireland who studied the unfossiliferous sandstones; to M. Gravelle, University of Brest; to the reviewers, J. R. Graham and P. Vidal, for useful discussions and suggestions; and to the scientific staff of Leg 80 who provided the basement samples.

\section{REFERENCES}

Allen, K. C., 1965. Lower and middle Devonian spores of north and central Westspitsbergen. Paleontology, 8(4):687-748.

Auffret, G. A., Pastouret, L., Cassat, G., De Charpal, O., Cravatte, J., and Guennoc, P., 1979. Dredged rocks from the Armorican and Celtic margins. In Montadert, L., Roberts, D. G., et al., Init. Repts. DSDP, 48: Washington (U.S. Govt. Printing Office), 995-1014.

Bailey, R. J., 1975. Sub-Cenozoic geology of the British continental margin (lat. $50^{\circ} \mathrm{N}$ to $57^{\circ} \mathrm{N}$ ) and the re-assembly of the North Atlantic late Paleozoic supercontinent. Geology, 10:591-594.

Deunff, J., 1971. Microfossiles organiques du Paléozoïque. 3-Les acritarches. Le genre Polyedryxium-Révision et observation. Comm. Int. Microflore Paleozoique, Cent. Nat. Rech. Sci., pp. 148. 
Dingle, R. V., and Scrutton, R. A., 1979. Sedimentary succession and tectonic history of a marginal plateau (Goban Spur, southwest of Ireland). Mar. Geol., 33:45-69.

Friend, P. F., 1969. Tectonic features of Old Red sedimentation in North Atlantic border. Mem. Am. Assoc. Pet. Geol., 12:703-710.

Haworth, R. T., and Lefort, J. P., 1979. Geophysical evidence for the extent of the Avalon zone in Atlantic Canada. Can. J. Earth Sci., 16:552-567.

Lanninger, E. P., 1968. Sporen-Gesellschaften aus dem Ems der SWEifel. Palaeontographica, 122B:95-170.

Lefort, J. P., and Haworth, R. T., in press. Geophysical evidence for the extension of the Variscan Front south of the Labrador Sea: Geodynamic and paleogeographic consequences. J. Geol. Soc. London.

Lefort, J. P., and Max, M.D., in press. Development of the Porcupine Seabight: the direct relationship between early oceanic and continental structures. J. Geol. Soc. London.

Lele, K. M., and Streel, M. 1969. Middle Devonian (Givetian) plant microfossils from Goé (Belgium). Ann. Soc. Geol. Belg., 92: $89-121$.

McGregor, D. C., 1973. Lower and middle Devonian spores of eastern Gaspé, Canada. I: Systematics. Palaeontographica, 142B:1-77.

Matthews, S. C., 1974. Exmoor Thrust? Variscan Front? Proc. Ussher Soc., 3:82-94.
Max, M. D., 1975. Precambrian rocks of South-east Ireland. Spec. Rept. Geol. Soc. London, 6:96-101. , 1979. Geotectonic map of Ireland. Atlas of Ireland (Sheet 5, Southwest): Dublin (Dublin Inst. Adv. Stud.).

Max, M. D., and Lefort, J. P., in press. Does the Hercynian Front in Ireland follow a dextral shear zone. J. Geol. Soc. London.

Pautot, G., Renard, V., Auffret, G., and Pastouret, L., 1976. A granite cliff deep in the North Atlantic. Nature, 263:669-672.

Richardson, J. B., 1965. Middle Old Red Sandstone spore assemblages from the Orcadian Basin, North-east Scotland. Paleontology, 7(4):559-605.

Robinson, K. W., Shannon, P. M., and Young, D. G. G., 1981. The Fastnet Basin: an integrated analysis. In Illing, L. V., and Hobson, G. D. (Eds.) The Geology of the Continental Shelf of North-West Europe: London (Heyden and Son Ltd.), pp. 444-454.

Vidal, P., 1976. Lévolution polyorogénique du Massif Armoricain: Apport de la géochronologie et de la géochimie isotopique du strontium [Thesis]. University of Rennes, France.

Wicander, E. R., 1974. Upper Devonian-lower Mississippian acritarchs and prasinophycean algae from Ohio, USA. Palaeontographica, 148B:9-43.

Date of Initial Receipt: January 5, 1983

Date of Acceptance: March 14, 1983

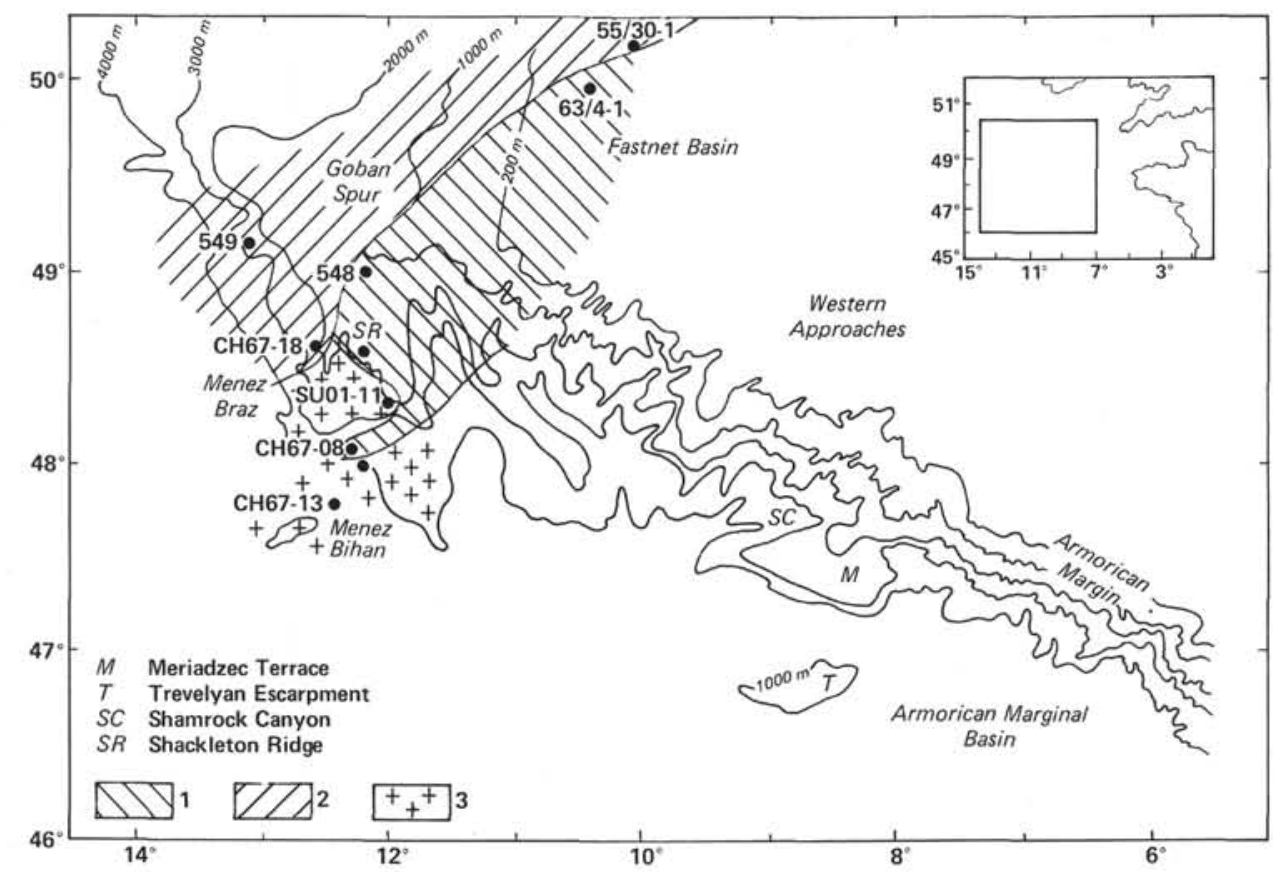

Figure 1. Distribution of the basement rock samples recovered between the Fastnet Basin and Menez Braz. 1-shale and slate basin, 2-sandstone ridge, 3-plutono-metamorphic zone. Sample locations after Pautot et al., 1976; Auffret et al., 1979; Dingle and Scrutton, 1979; and Robinson et al., 1981. 